Copyright (C) 2021 by Cherkas Global University

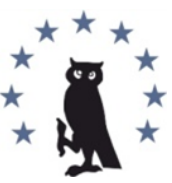

Published in the USA

Russkii Arkhiv

Has been issued since 1863 .

E-ISSN: 2413-726X

2021. 9(2): 181-188

DOI: $10.13187 /$ ra.2021.2.181

https://ra.cherkasgu.press

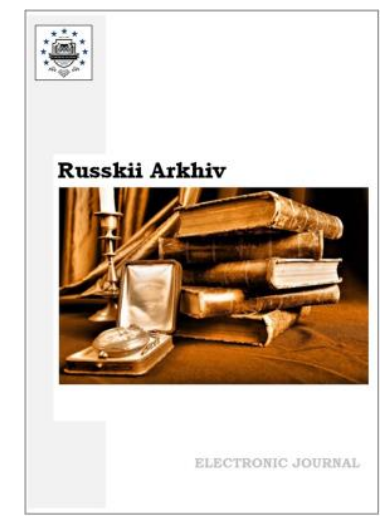

\title{
Ruined Home. From the History of Stanitsa Ubezhenskaya during the Soviet Period Through the Eyes of an Eyewitness
}

Preparation for publication, introductory article and comments

Igor G. Ivantsov a, *, Igor V. Dubinin ${ }^{\mathrm{b}}$

${ }^{\text {a }}$ Krasnodar Higher Military School, Russian Federation

b Dinskaya Mechanical Engineering College, Russian Federation

\begin{abstract}
Modern historical research on the history of everyday life in Russia during the Soviet period is a reflection of the "spirit of the times". A certain rise in historical research at the beginning of the $21^{\text {st }}$ century is characterized by the mass use, for this purpose, of various kinds of memories, private letters, other sources of personal origin, telling about the lives of individuals, communities, settlements in conditions of instability, various kinds of social upheavals, so characteristic of the Soviet period of Russian history, especially for its first half. It is in this case that written sources of personal origin are sometimes indispensable for the development of research on the history of everyday life, microhistory of communities and other areas. So, it is important to refer to the recorded memoirs of contemporaries, a certain fashion for which arose already in the second half of the 1980s. This article is based on one of such sources, about the history of the village Ubezhenskaya, Uspensky district, Karasnodar krai, in Soviet period viewed by its inhabitant, Nikolay Ivanovich Zotov, eyewitness of the epoch.
\end{abstract}

Keywords: memories, everyday life, past events, eyewitness accounts, stanitsa Ubezhenskaya.

Помимо официальных документов, все чаще в научной литературе можно встретить различные источники личного происхождения (Матишов и д., 2009; Кринко и др., 2011; Матишов и др., 2016; Сенявская и др., 2017; Лебина, 2018 и др.). В данной связи значительный интерес для исследователей представляют и материалы личных собраний (архивов) граждан. На сегодняшний день истории повседневности, микроистории сообществ посвящен целый ряд исследований. Все они имеют важное значение, позволяя реконструировать жизнь рядового человека прошедших времен.

Воспоминания Николая Ивановича Зотова о станице Убеженской Краснодарского края были любезно предоставлены его внуком Игорем Николаевичем Пономаревым, проживающим в г. Краснодаре.

Зотов Николай Иванович родился 10 сентября 1918 г. в городе Хасавюрт Дагестанской АССР. Образование - 7 классов начальной школы. Гражданская специальность - техниксъемщик. В 1939 г. был призван в ряды Вооруженных сил СССР. Участник Великой

\footnotetext{
${ }^{*}$ Corresponding author

E-mail addresses: IIG23@yandex.ru (I.G. Ivantsov)
} 
Отечественной войны. Служил в 1-м дивизионе, во взводе управления дивизионом (ВУД) 360-го гаубичного артиллерийского полка Артиллерийского резерва Главного командования (АРГК)․․

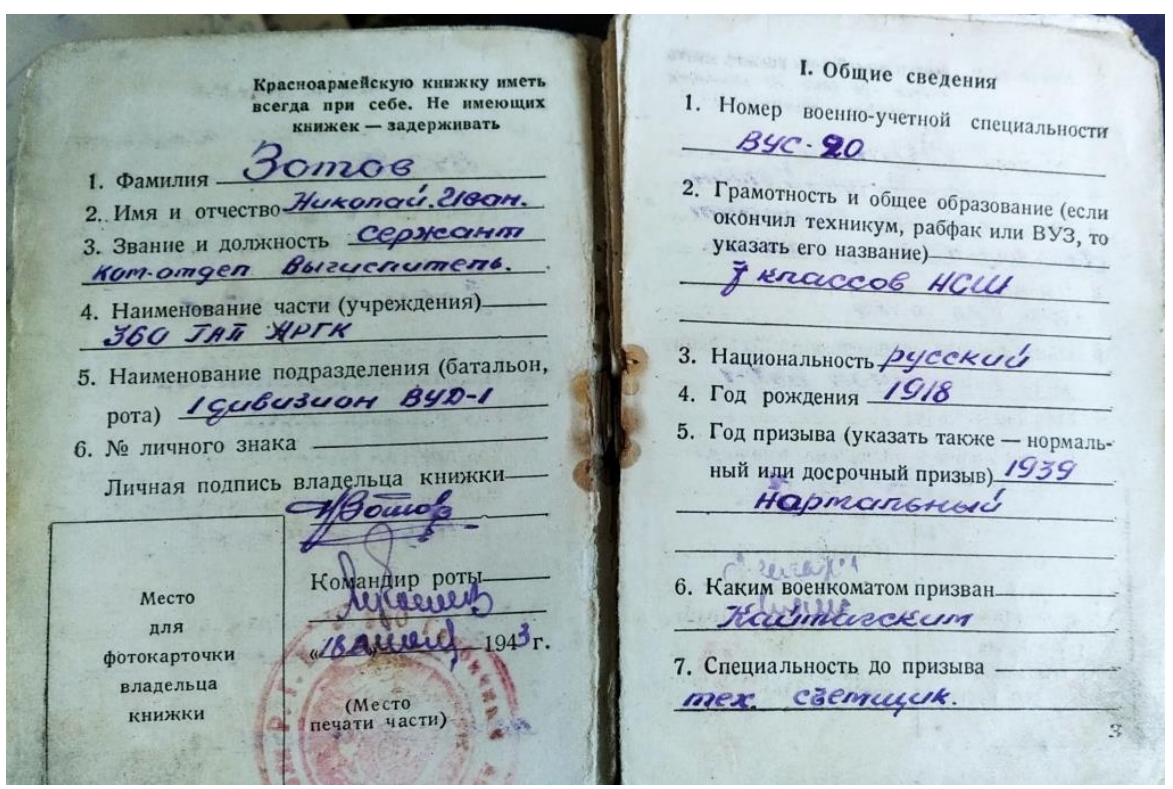

Рис. 1. Красноармейская книжка Н.И. Зотова. Фото из личного архива И.Н. Пономарёва

За участие в Великой Отечественной войне Н.И. Зотов был награжден орденом Красной звезды и медалями «За боевые заслуги», «За победу над Германией», «За взятие Праги».

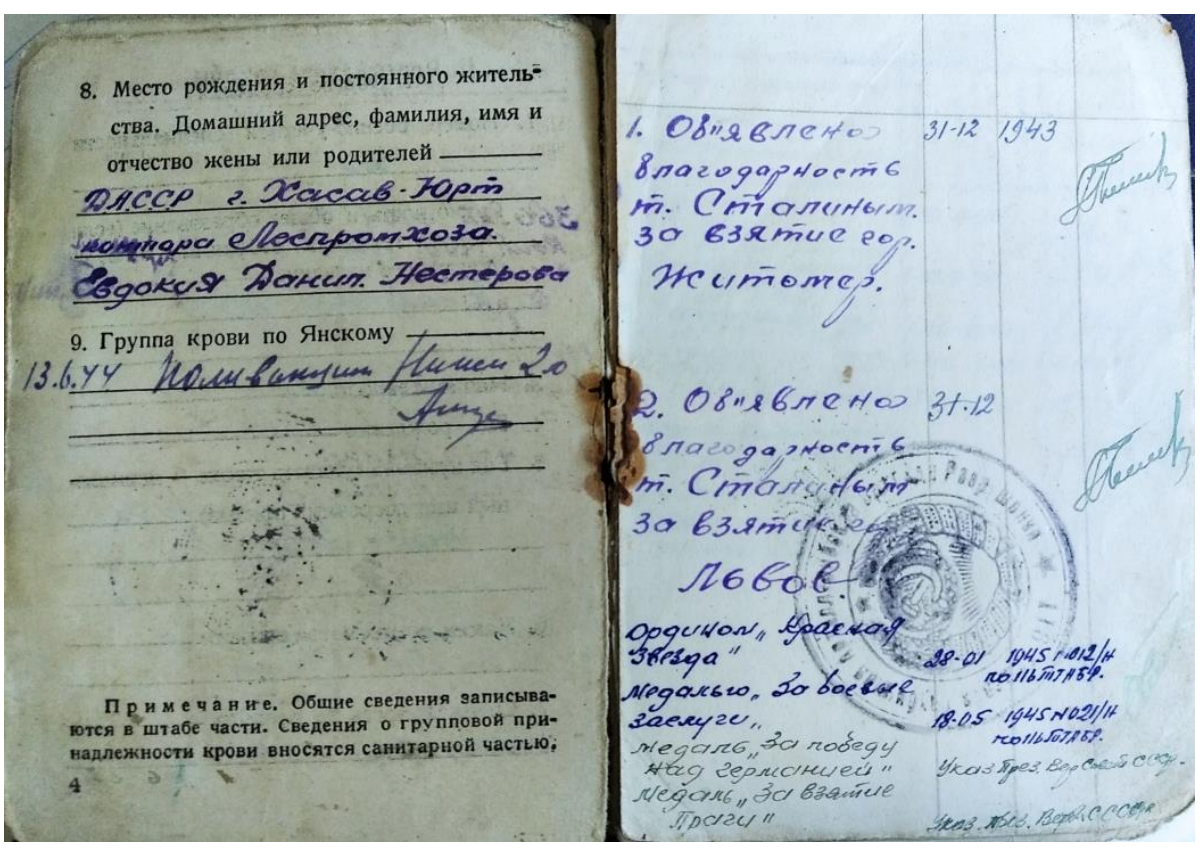

Рис. 2. Сведения о боевых наградах Н.И. Зотова в его красноармейской книжке Фото из личного архива И.Н. Пономарёва

1 36о-й гаубичный артиллерийский полк находился в действующей армии во время Великой Отечественной войны с 22 июня 1941 г. 11 сентября 1943 г. был преобразован в 116-ю тяжелую гаубичную артиллерийскую бригаду. 
По окончании Великой Отечественной войны Н.И. Зотов был демобилизован из Вооруженных сил СССР. После войны вместе с матерью переехал в станицу Убеженскую на постоянное место жительства, где проживали его родственники. Умер 9 мая 1993 г.

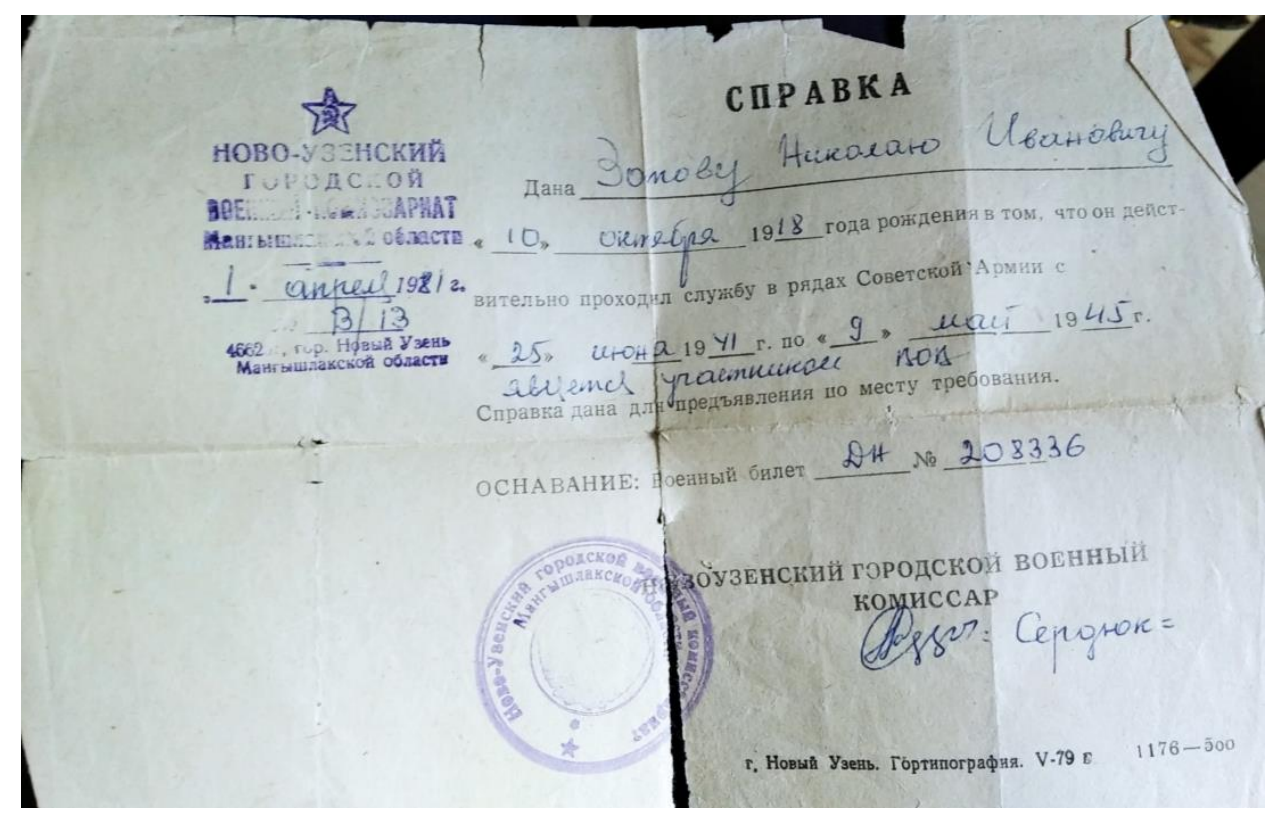

Рис. 3. Справка участника и ветерана Великой Отечественной войны Н.И. Зотова. Выдана в 1981 г. Фото из личного архива И.Н. Пономарева

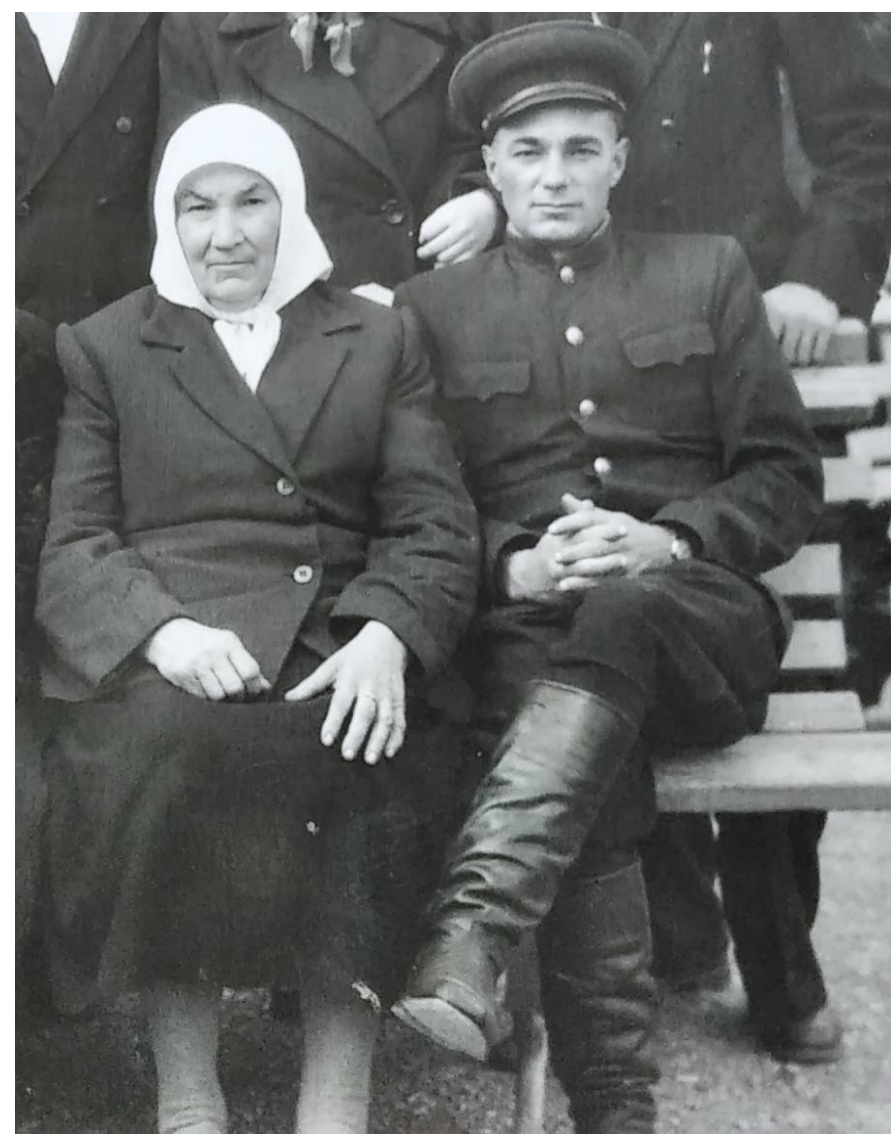

Рис. 4. Николай Иванович Зотов с матерью Евдокией Даниловной Нестеровой. Вторая половина 1940-х гг. Фото из личного архива И.Н. Пономарева 
Рукопись содержит воспоминания Николая Ивановича Зотова о жизни станицы Убеженской. Текст написан от руки на восьми пожелтевших листах писчей бумаги. Девятый лист - рисунок дома семьи Николая Ивановича в 1930-1933 гг., сделанный им по памяти на обратной стороне листа со следами от дырокола и с машинописным текстом, не относящимся к содержанию публикуемого источника.

Текст воспоминаний публикуется в соответствии с современными нормами орфографии и пунктуации. В квадратных скобках приведены недостающие слова.

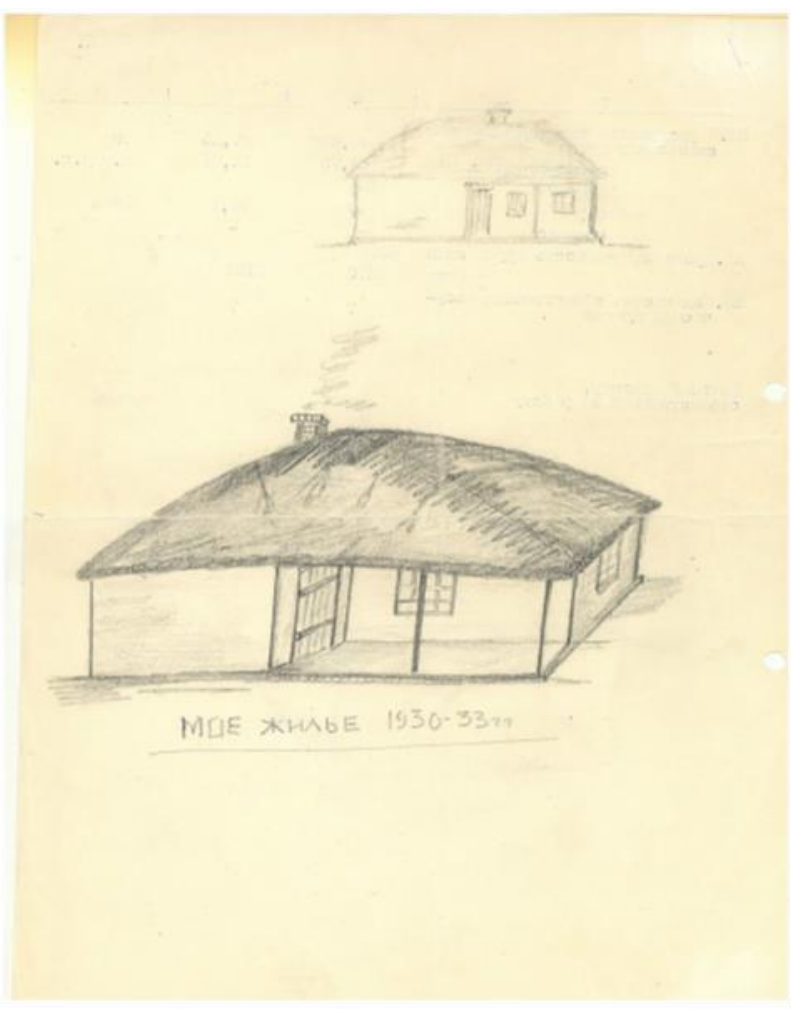

Рис. 5. Рисунок Н.И. Зотова, изображающий дом его семьи в станице Убеженской в 1930-1933 гг. Рисунок сделан по памяти в 1990 г.

\section{Из истории станицы Убеженской советского периода}

С высокого левого берега реки Кубани, что у п[оселка] Марьиноㄹ, хорошо смотрится станица Убеженская². Узкие кривые улицы станицы растянулась по правому берегу Кубани порядка 8 километров. Лет 6о-7о [назад] она [была заселена] почти от хутора Западного до моста через реку старой железнодорожной ветки Армавир-Ставрополь. По рассказам старожилов железная дорога действовала до 1926 г. Во время большого ледохода несколько деревянных пролетов в средней его части были разрушены. Восстанавливать [мост] частный владелец Мануйлов не стал. И тогда связи с г. Армавиром стали осуществляться через мост у станицы Прочноокопской 3 . Проселочная дорога от разрушенного моста и до станицы Прочноокопской пролегала по правому берегу Кубани по косогору в очень трудных условиях, особенно в осенне-зимний период.

Станица Убеженская свое начало берет с 1827 г. Ее первым поселенцем и основателем был казак Кабельков. Свое столетие станица отмечала в 1927 г. Празднование проводилось

\footnotetext{
${ }^{1}$ Марьино - село в Успенском районе Краснодарского края. Входит в состав Вольненского сельского поселения.

2 Убеженская - станица в Успенском районе Краснодарского края. Административный центр Убеженского сельского поселения.

3 Прочноокопская - станица в Новокубанском районе Краснодарского края. Административный центр Прочноокопского сельского поселения.
} 
на площади (выгоне). Здесь в этот день были и стар, и млад. Чтобы привлечь и развлечь станичников были организованы скачки, джигитовки. Установили качели, продавались пряности ${ }^{1}$, с бочек хлебный квас, мороженое. Казаки, как правило, в черкесках с башлыками, казачки в персидских платках с красиво расшитыми кофточками, длинными юбками в гусарах ${ }^{2}$. Празднование происходило шумно и весело.

Свое название Убеженская получила от слова Убежище, где скрывались военнопленные казаки, таково предание.

Росла и богатела станица, и только по истечении 80 лет в станице была построена белокаменная церковь с пятью куполами и звонницей. Строительство велось на средства зажиточного казачества и жителей станицы. Величие и красота этой церкви была как с внешней стороны, так и внутри. По колокольному звону жители станицы, где бы они не находились: в поле или дома, могли определить время рождения, свадьбы, ухода человека в потусторонний мир. И каждый, перекрестившись, желал «царство ему небесное».

Вокруг церкви в расстоянии 100 метров (ромбообразно) располагались 5 кирпичных школ: четыре начальных одноэтажных с большими классами и окнами и одна 2-х этажная Г-образной формы с полуподвальными спортивными залами. При школе был небольшой фруктовый садик, сторожка, складской сарай. В школах до Октябрьской революции учились в основном дети состоятельных казаков. После - все желающие.

Октябрьскую революцию, принесшую советскую власть, казачество станицы приняло не сразу. Много в ней было непонятного, убедительного. Бедные считали и ждали манну небесную; зажиточные упорно сомневались в этой щедрости. Отпраздновали в 1927 г. 10-летие Октябрьской Социалистической революции. В станице продолжает существовать единоличное хозяйствование, каждый трудится на своем земельном наделе. Излишки сдавали государству, остальное по едокам оставляли у семей.

До начала коллективизации и раскулачивания (1929-1932 гг.) в станице проживало 18 тысяч человек или 3600 дворов. До этого времени в станице имелось: 5 мельниц (владельцами их были Мануйлов, Суханов, Яковлев, Ковта, Бардуков). Одна маслобойня, четыре медодавки, четыре передвижных молотилки (Яковлева, Мануйлова, Суханова, Краморова).

Из торговых в станице имелось: две лавки и три сельских магазина. Из медицины один медицинский пункт, где был фельдшер Сизов. Земельные наделы на каждого члена семьи казачьего сословия выделялось по 6 десятин. Иногородним земля не давалась. Сельское хозяйство станичников было занято выращиванием пшеницы, ячменя, овса, кукурузы, подсолнечника, свеклы. Из садоводства: яблоки, груши, сливы, вишня, виноград - столовый и винодельный.

Имелось в станице кредитное товарищество, однако сельхозпродукция в большинстве своем вывозилась в город Армавир. Который находился в 18 км от станицы. Там имелись беконная фабрика, маслозаводы, мельницы, кондитерские фабрики и другие предприятия по переработке сельхозпродукции. Впервые при единоличной системе в станице в 1929 г. была организована коммуна с названием «Борцы труда». Объединилась она из наиболее имущих казаков. Они объединили свой сельхозинвентарь, тягловую силу - быков, лошадей. Землю им выделили близ станицы между рекой Кубанью и железной дорогой АрмавирСтаврополь. Здесь они выращивали, кроме существовавших зерновых, технических культур, - сою, белокочанную кукурузу «Веретенка». Стебли ее были низкорослые, но зато на каждом стебле по два крупных початка.

Урожаи коммунары получали отменные. Трудились они дружно, организованно со знанием дела. Продукцию распределяли по затраченному труду каждой семье. Часть выращенной продукции сдавали и продавали государству. Но не долго просуществовала коммуна «Борцы труда». Кто-то острым оком усмотрел, что коммуна состоит не из бедняков и батраков, а зажиточных, и [ее] ликвидировали. Большинству навесили ярлык «кулака», раскулачили и сослали в отдаленные места. Началось с 1930-1931 гг. раскулачивание и добровольно-принудительное вовлечение в колхоз. Некоторые смышленые бросали свои очаги, хватали необходимое и бежали кто куда! Кто в Грузию, кто в Закавказье, а кто

\footnotetext{
${ }^{1}$ Вероятно, различные сладости.

2 Женская длинная юбка, обильно расшитая петлями, веревками, пуговицами.
} 
в Дагестан. Спаслись от этого мероприятия не многие. У кого было золотишко, серебро, ум и грамотишка ${ }^{1}$. Так как без справок, что «колхоз разрешил», ты «бедняк» или «середняк». Без этой справчонки тебя ни одна организация в Союзе на работу не примет. А без работы ты не жилец, а скрывающийся «враг народа»... И, пожалуй, без суда и следствия на 10 лет туда, «где Макар телят не пас».

Ярлык «кулака», «врага народа» можно было получить и не по имущественному цензу, а по доносу. А таких было немало. В станице, как сказал ее старожил Иван Семенович Иванов, было организованно двенадцать колхозов, название которых он уже и не припомнит. Один из них, в котором он был его членом, носил фамилию «Пивоварова». Председателем колхоза был Иван Кузьмич Кавун.

С 1932 по 1933 гг. станицу постигла большая трагедия - «голод». Голодомор охватил не только станицу, но и Краснодарский, Ставропольский края, Ростовскую область², южную Украину и другие регионы Союза. Иван Семенович Иванов рассказывал, [что] будучи бригадиром, лично выделял подводу и группу из 6-7 человек, которым было поручено каждый день объезжать дома и собирать умерших. Трупы складывали на подводу и вывозили на кладбище, где было вырыто две ямы, и туда сваливали. Среди умерших были старики, дети, и просто взрослые люди. Умерших не зарывали. Такая процессия длилась с поздней осени 1932 г. и до наступления тепла 1933 г. Умирали от голода не только отдельные члены семьи, а вся семья, фамилия. Оставались пустые дома.

Был такой страшный случай - продолжает Иван Семенович - в одном доме забрали последнюю умершую. Погрузили на подводу. Подъехали к другому. Пока осматривали дом, умершая почувствовала, что она среди трупов. Собрав последние силы, сползла с подводы и уползла в бурьян. Соседи подобрали, накормили, чем могли. Сейчас она жива, ей где-то под 70 лет. Одним словом, «живой труп», но не от сытости.

Был и такой случай. Одна гражданка закопала своего ребенка, а потом выкопала и съела. За время с 1929 г. по 1933 г., когда вершилось в станице раскулачивание, коллективизация и последняя трагедия голодомор - станица потеряла около 75 \% от общей численности своих станичников (13,5 тыс. человек). В настоящее время в станице проживает 1450 человек. Имеются одна средняя школа. Из старых жилых домов сохранилось порядка 30. Из промышленных предприятий в станице пока ничего нет. Планируется строительство мельницы.

До 1929 г. в частном секторе станицы имелось до 7,2 тыс. крупного рогатого скота, лошадей 8 тыс., свиней 10,8 тыс. штук. Овец более 18 тысяч, птицы разной до 100 тыс. штук.

В настоящее время колхоз «Путь к коммунизму» имеет в своем распоряжении 13 тыс. га земель, имеет 3 тыс. голов крупного рогатого скота, лошадей 10 пар, овец 18 тыс., птицы более 5 тыс. штук. В частном владении: коров 182 штуки, свиней 220 штук, птицы всякой 13 тыс. штук, овец 300 голов. Имеется два магазина: продовольственный, хозяйственный. Рядом с правлением колхоза расположен мемориал погибшим станичникам в Великой Отечественной войне, где занесено 200 фамилий! Это, видимо, те, чьи родственники остались в живых. Они-то и подсказали. Действительных данных нет. На самом же деле станичников погибло в несколько раз больше. Когда страна была в опасности, райвоенкоматы призывали и знали где, кто проживает, ф[амилию], и[мя], о[тчество] и год рождения. Теперь же «никто не забыт, ни что не забыто» оказалось фальшиво. Те, кто обязан был знать и помнить, нарочито отупели, а люди остались безымянными.

На кладбище поставлен памятник погибшим при сталинских репрессиях с 1930 по 1940 гг., где значится порядка 30 человек. Явно неправдоподобно. А как считать тех, чей прах лежит в 2-х силосных ямах. Сколько их, кто они. А ведь они имели фамилии, имена, отчества. Все это лежит на совести оставшихся в живых. И вот спустя 57 лет над этими ямами нет мемориала жертвам голодомора. А надо чтобы он стал местом скорби и поклонения. Это нужно не для мертвых, это нужно для живых.

\footnotetext{
1 Под грамотой («грамотишкой») Н.И. Зотов подразумевает документы, удостоверявшие личность и справки из сельсовета об отсутствии задолженностей по налогам, ссудам и т.д.

2 В 1932-1933 гг. Краснодарского и Ставропольского краев, Ростовской области не существовало, а их территория входила в состав Северо-Кавказского края.
} 
Жительница станицы Татьяна Угримова рассказывала: «За свои 55 лет работы в колхозе, кем ей только не приходилось быть: свинаркой и дояркой, скотницей и овощеводом, птичницей и шелководом. Мужа, бригадира тракторной бригады Сергея Кирилловича по доносу арестовали в 1935 г., и [он] не вернулся. Она с двумя детьми осталась одна и кормилицей, и воспитателем. Жилось, не дай бог другим.

Колхоз наш «Путь к коммунизму» был как проходной двор. За эти 58 лет сменилось почти 30 председателей колхоза. Каких только национальностей не было. Если бы каждый (из председателей) оставался в станице - был бы хороший поселок, но этого не случилось. Каждый старался строить себе жилье в городе, и с окончанием своего срока, оставлял станицу, а в ней и нас. Все эти радетели настолько обдирали колхоз, что мы ни разу не поднимались до середняка. Мы привыкли к обещаниям светлого будущего, но, наверное, его не дождемся. Молодежь из станицы уходит, а мы стареем и уходим из жизни.

Прошло 6о лет от этого «сталинского удара», а станица не может подняться и сегодня.

20 ноября 1990 г.

Н.И. Зотов

\section{Литература}

Кринко и др., 2011 - Кринко Е.Ф., Тажидинова И.Г., Хлынина Т.П. Повседневный мир советского человека 1920-1940-х гг.: жизнь в условиях социальных трансформаций. Ростовна-Дону: Изд-во ЮНЦ РАН, 2011. 360 с.

Лебина, 2018 - Лебина Н.Б. Советская повседневность: нормы и аномалии. М.: Новое литературное обозрение, 2018. 482 с.

Матишов и др., 2016 - Матишов Г.Г., Афанасенко В.И., Кринко Е.Ф., Медведев М.В. Большая излучина Дона - место решающих сражений Великой Отечественной войны (1942-1943 гг.). Ростов-на-Дону: Издательство ЮНЦ РАН, 2016. 456 с.

Матишов и др., 2009 - Матишов Г.Г., Кринко Е.Ф., Власкина Н.А., Бритвина E.A. Социально-исторический портрет села Приазовья: Кагальник. Ростов-на-Дону: Изд-во ЮНЦ РАН, 2009. $208 \mathrm{c}$.

Морозова, 2010 - Морозова О.М. Цари, казаки, красные командиры... : семь очерков в жанре историко-психологического портрета. Ростов-на-Дону: Изд-во ЮНЦ РАН, 2010. 274 с.

Сенявская и др., 2017 - Сенявская E.С., Сенявский А.С., Жукова Л.В. Человек и фронтовая повседневность в войнах России XX века. Очерки по военной антропологии. М.: Центр гуманитарных инициатив, 2017. 418 с.

\section{References}

Krinko i dr., 2011 - Krinko, E.F., Tazhidinova, I.G., Hlynina, T.P. (2011). Povsednevnyj mir sovetskogo cheloveka 1920-1940-h gg.: zhizn' v usloviyah social'nyh transformacij [The everyday world of the Soviet man of the 1920-1940s: life in the conditions of social transformations]. Rostov-on-Don: SSC RAS Publishers, 359 p. [in Russian]

Lebina, 2018 - Lebina, N.B. (2018). Sovetskaya povsednevnost': normy i anomalii [Soviet everyday life: norms and anomalies]. Moscow: Novoe literaturnoe obozrenie, 482 p. [in Russian]

Matishov i dr., 2016 - Matishov, G.G., Afanasenko, V.I., Krinko, E.F., Medvedev, M.V. (2016). Bol'shaya izluchina Dona - mesto reshayushchikh srazheniy Velikoy Otechestvennoy voyny (1942-1943 gg.) [The big bend of the Don River - a place of decisive battles of the Great Patriotic War (1942-1943)]. Rostov-on-Don: SSC RAS Publishers, 456 p. [in Russian]

Matishov i dr., 2009 - Matishov, G.G., Krinko, E.F., Vlaskina, N.A., Britvina, E.A. (2009). Sotsial'no-istoricheskiy portret sela Priazov'ya: Kagal'nik [A Social-historical portrait of a village of the Azov region: Kagalnik]. Rostov-on-Don: SSC RAS Publishers, 208 p. [in Russian]

Morozova, 2010 - Morozova, O.M. (2010). Tsari, kazaki, krasnye komandiry... : sem' ocherkov v zhanre istoriko-psikhologicheskogo portreta [Tsars, Cossacks, Red Commanders ...: Seven Essays in the Genre of Historical and Psychological Portrait]. Rostov-on-Don: SSC RAS Publishers, 274 p. [in Russian]

Senyavskaya i dr., 2017 - Senyavskaya, E.S., Senyavskiy, A.S., Zhukova, L.V. (2017). Chelovek i frontovaya povsednevnost' v voynakh Rossii XX veka. Ocherki po voennoy antropologii [Man and front-line everyday life in the wars of Russia in the XX century. Essays on military anthropology]. Moscow: Tsentr gumanitarnykh initsiativ, 418 p. [in Russian] 


\section{Разоренный очаг. Из истории станицы Убеженской советского периода глазами очевидца}

Подготовка к публикации, вступительная статья и комментарии

Игорь Григорьевич Иванцов ${ }^{\text {a }}$ * , Игорь Владимирович Дубинин ${ }^{\text {b }}$

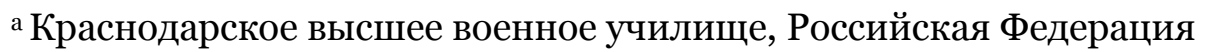

b Динской механико-машиностроительный техникум, Российская Федерация

Аннотация. Современные исторические исследования по истории повседневности России советского периода являются отражением «духа времени». Определенный подъем исторических изысканий начала в начале XXI в. характерен массовым использованием, с этой целью, различного рода воспоминаний, личных писем, иных источников личного происхождения, повествующих о жизни отдельных людей, сообществ, населенных пунктов в условиях нестабильности, различного рода общественных потрясений, так характерных для советского периода русской истории, особенно для первой его половины. Именно в этом случае письменные источники личного происхождения являются порой незаменимыми для развития исследований по истории повседневности, микроистории сообществ и других направлений. И здесь важным является обращение к записанным воспоминаниям современников, определенная мода на которые возникла уже во второй половине 1980-х гг. Данная статья опирается на один из таких источников, об истории станицы Убеженской Успенского района Краснодарского края советского периода глазами ее жителя, Николая Ивановича Зотова, свидетеля эпохи.

Ключевые слова: воспоминания, повседневность, прошедшие события, свидетельства очевидца, станица Убеженская.

* Корреспондирующий автор

Адрес электронной почты: IIG23@yandex.ru (И.Г. Иванцов) 